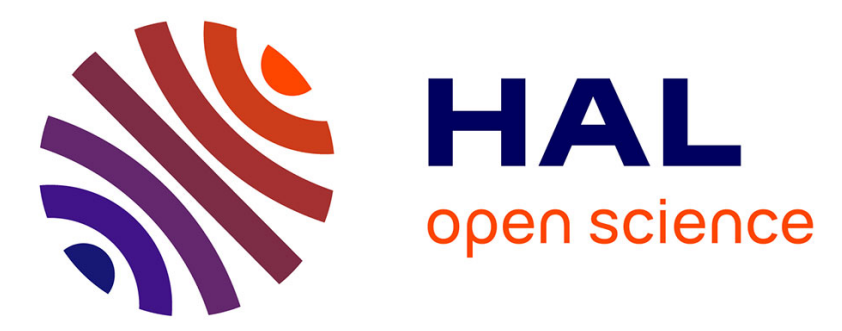

\title{
Bottom-up processes control benthic macroinvertebrate communities and food web structure of fishless artificial wetlands
}

Florian Mermillod-Blondin, Pierre Marmonier, Mélissa Tenaille, Damien

Lemoine, Michel Lafont, Ross Vander Vorste, Laurent Simon, Laurence

\section{Volatier}

\section{To cite this version:}

Florian Mermillod-Blondin, Pierre Marmonier, Mélissa Tenaille, Damien Lemoine, Michel Lafont, et al.. Bottom-up processes control benthic macroinvertebrate communities and food web structure of fishless artificial wetlands. Aquatic Ecology, 2020, 54, pp.575-589. 10.1007/s10452-020-09760-2 . hal-02515841

\section{HAL Id: hal-02515841 \\ https://univ-lyon1.hal.science/hal-02515841}

Submitted on 10 Dec 2020

HAL is a multi-disciplinary open access archive for the deposit and dissemination of scientific research documents, whether they are published or not. The documents may come from teaching and research institutions in France or abroad, or from public or private research centers.
L'archive ouverte pluridisciplinaire HAL, est destinée au dépôt et à la diffusion de documents scientifiques de niveau recherche, publiés ou non, émanant des établissements d'enseignement et de recherche français ou étrangers, des laboratoires publics ou privés. 
1 TITLE: Bottom-up processes control benthic macro-invertebrate communities and food web

2 structure of fishless artificial wetlands

3

4 Authors: Florian Mermillod-Blondin F. ${ }^{*}$, Pierre Marmonier ${ }^{1}$, Mélissa Tenaille ${ }^{1}$, Damien G.

5 Lemoine ${ }^{1}$, Michel Lafont ${ }^{1}$, Ross Vander Vorste ${ }^{2}$, Laurent Simon ${ }^{1}$, Laurence Volatier ${ }^{1}$

6

$7 \quad{ }^{1}$ UMR 5023 LEHNA, Université de Lyon, CNRS, Université Claude Bernard Lyon 1, ENTPE, 6

8 rue Raphaël Dubois, 69622 Villeurbanne, France.

$9 \quad{ }^{2}$ Department of Biology, University of Wisconsin, WI 54601, La Crosse, USA.

$10 *$ Corresponding author: Florian Mermillod-Blondin

11 UMR 5023 LEHNA, Université de Lyon, CNRS, Université Claude Bernard Lyon 1, ENTPE, 6

12 rue Raphaël Dubois, 69622 Villeurbanne.

13 E-mail: florian.mermillod-blondin@univ-lyon1.fr

14 Phone number: (33) 472431364

15 Fax number: (33) 472431141 


\section{Abstract}

18 In freshwater environments, the relative contributions of top-down and bottom-up effects on 19 invertebrate communities in relation to productivity are largely ecosystem dependent. Artificial 20 wetlands are increasingly developed to compensate for the loss of natural wetlands however their

21 trophic processes remain poorly studied. The present study aimed to evaluate the respective 22 contributions of bottom-up and top-down processes in structuring benthic food webs of three 23 artificial wetlands with varying levels of benthic primary productivity. We found that phototrophic-

24 based food webs in our artificial wetlands were controlled from the bottom-up by primary 25 productivity and algal biomass developing at the water-sediment interface. No significant top26 down-control of herbivore species by invertebrate predators was detected even in the wetland with

27 the highest productivity. Increased richness of invertebrate grazers and scrapers with benthic 28 primary productivity and algal biomass might have dampened the trophic cascade from predators 29 to primary producers. In contrast with the phototrophic-based food web, analyses performed on the detritus-based food web showed that deposit-feeder invertebrate abundance was not correlated with

31 the quantity of organic matter in sediments, suggesting a weak bottom-up effect of sedimentary 32 organic matter content on deposit-feeders. More surprisingly, deposit-feeders, especially aquatic oligochaetes, seemed to influence the detritus-based food webs by stimulating organic matter

34 processing and bacterial growth through bioturbation. The present study highlighted the occurrence 35 of contrasting trophic processes between phototrophic-based and detritus-based food webs which 36 can have implications on ecosystem functions, such as nutrient cycling and energy fluxes.

38 Keywords: functional feeding groups, benthic food webs, invertebrates, benthic biofilm, algae, bacteria, 39 trophic relationships 
41 The relative importance of bottom-up and top-down controls on the structure of communities has

42 long been an intense debate (Oksanen et al. 1981; Hunter and Price 1992; Polis and Strong 1996;

43 Gruner et al. 2008). The exploitation ecosystem hypothesis (EEH) predicts that resource

44 availability and predation control densities within adjacent trophic levels (Oksanen et al. 1981).

45 Accordingly, increasing primary productivity lengthens food webs by boosting the establishment

46 of predators, that will, in turn, have a greater impact on lower trophic levels. In nutrient-poor

47 ecosystems, biomass of basal species is severely constrained by resource availability and is too low

48 to support a significant consumer biomass (Menge 2000). In more nutrient-rich ecosystems,

49 productivity of basal species increases with elevated resources but their biomass is kept constant

50 by predation as consumers become more abundant (Steiner 2001). Although it has been shown that

51 the predictions of EEH are modulated by biotic (e.g., diversity of the food webs) and abiotic (e.g.,

52 habitat heterogeneity, disturbance) factors (Hunter and Price 1992; Leibold et al. 1997; Menge et

53 al. 2002; Foulquier et al. 2011), it provides a robust theoretical framework to evaluate the roles of

54 bottom-up and top-down controls on ecosystem structure (e.g., Shurin et al. 2002; Aunapuu et al.

55 2008; Lezama et al. 2014; Du et al. 2015; Hoset et al. 2017).

56 In wetlands, a historical view that bottom-up controls have greater relative importance than top-

57 down controls in regulating ecosystem structure and function (e.g., Odum and Smalley 1959) has

58 been reconsidered more recently (Sala et al. 2008; Moore 2018). Indeed, top predators like fish or

59 invertebrates can significantly control the abundance and the assemblage of their prey (Diehl 1992;

60 Magnusson and Williams 2009; Cobbaert et al. 2010; Laske et al. 2017) and top-down control of

61 grazers on primary producers play a key role on wetland functioning and stability (e.g., limitation

62 of algal blooms; Hillebrand 2009; Bertness et al. 2014). In this context, artificial wetlands, which 
63 are increasingly developed to compensate for the loss of natural wetlands (Davidson 2014), could 64 be useful tools for determining the respective roles of bottom-up and top-down forces on 65 community structures because they allow for the selection of systems with distinct productivities.

66 Moreover, these artificial systems may be managed for controlling the water flux of organisms, 67 reducing the heterogeneity in biological colonization among wetlands (De Meester et al. 2005).

68 We tested the predictions of EEH in shallow (water depth $<1.5 \mathrm{~m}$ ) artificial wetlands having area 69 of less than 2 ha and benthic habitat characterized by dense biofilms of phototrophic and 70 heterotrophic micro-organisms (Gette-Bouvarot et al. 2014). To test the respective influences of 71 bottom-up and top-down controls on benthic invertebrate communities, we selected three fishless 72 shallow artificial wetlands characterized with contrasting primary productivities (estimated from 73 net photosynthesis of benthic biofilms) associated with differences in sediment composition 74 (proportion of clay and silt) and algal biomass at the water-sediment interface. We expected 75 components of the biofilms to play a key role as food sources for the benthic food web creating a 76 bottom-up effect. However, in accordance with the EEH we hypothesized the relative importance 77 of bottom-up and top-down effects to shift from a dominance of bottom-up controls to a dominance 78 of top-down controls with increasing primary productivity. To evaluate the response of food webs, we classified benthic invertebrate communities into trophic functional groups by including both the vertical (linear trophic chain from basal resources to predators through consumers) and

81 horizontal dimensions of food webs (species diversity at each trophic level, following Srivastava and Bell (2009). Under a bottom-up control scenario, we predicted a positive relationship between

83 the abundance of grazers and scrapers and primary productivity and algal biomass at the water84 sediment interface, a positive relationship between deposit-feeders (bacterivores) and bacterial 85 abundance and organic matter (\% of total organic carbon and total nitrogen) in sediment, and a positive relationship between macroinvertebrate predator abundance and the abundance of preys at 
87 lower trophic levels. Alternatively, under a top-down control scenario, we predicted no positive 88 relationships between consumers and their food sources.

\section{$90 \quad$ Material and Methods}

\section{Study site}

92 Our experiment took place in a pumping well field of «Crépieux-Charmy » $\left(3.75 \mathrm{~km}^{2}\right)$ located in

93 the Rhône River floodplain (France), which provides drinking water for the metropolitan area of

94 Lyon (1,280,000 inhabitants supplied). Artificial wetlands (surface area $=0.85-1.5$ ha) have been

95 built to recharge aquifer with river water. All wetlands were built by excavation in natural soils in

96 areas with reduced riparian vegetation and were partially filled with a layer of calibrated sand about

$9720 \mathrm{~cm}$ thick and characterized by a low organic matter content (total organic carbon $<0.1 \%$ of

98 sediment dry mass). Their main water supply is pumped in a channel (Vieux Rhône) of the Rhône

99 River using centrifugal pumps (rotation: 1000 rounds per minute) that markedly limit the transport

100 of top-predator fishes from Rhône River to wetlands. Despite similar designs, wetlands evolved

101 over time due to the accumulation of fine particles $(<63 \mu \mathrm{m})$ at the water-sediment interface,

102 influencing the availability of the benthic habitat for biofilms. Indeed, presence of fine sediments

103 on a coarse and poorly organic sediment ameliorate the physical attachment and the nutrient

104 availability for benthic biofilms (Sundbäck et al. 2003; van de Koppel et al. 2001; Watermann et

105 al. 1999). For the present study, we selected three wetlands (called A, B, C) that were characterized

106 by varying amounts of fine particles (proportions determined by laser diffractometry following

107 Estragnat et al. 2018) at the water-sediment interface (Fig. 1A, one-way ANOVAs, comparison of

108 fine sediment proportion among wetlands, $\left.F_{2,15}=29.6, \mathrm{p}<0.001\right)$, leading to contrasted benthic 
habitats for benthic biofilms. Following the decreasing gradient of fine particle amount from

110 wetland A to wetland C, algal biomass and net photosynthesis activity (see below for details on measurements) of the biofilm decreased from wetland A with a mean chlorophyll a content of 2.85

$112 \mu \mathrm{g}$ per $\mathrm{cm}^{2}$ and positive net production to wetland $\mathrm{C}$ with a mean chlorophyll a content of $1.55 \mu \mathrm{g}$

113 per $\mathrm{cm}^{2}$ and negative net production as photosynthesis did not compensate for respiration (Fig.

114 1BC, one-way ANOVAs, comparisons of algal biomass and net photosynthesis among wetlands, $115 F_{2,15}=26.6, \mathrm{p}<0.001$ for algal biomass, $F_{2,15}=23.6, \mathrm{p}<0.001$ for net photosynthesis). These 116 conditions allowed us to evaluate the trophic relationships between primary productivity, benthic 117 food sources, and invertebrate communities.

Environmental conditions before sampling date

119 The three studied wetlands had the same water supply and water column depth during a period of 1206 weeks before sampling date (on $22^{\text {nd }}$ of October 2014), minimizing the potential influence of 121 hydrological conditions on community structure. During this period, we also verified that the three 122 wetlands were characterized by comparable physico-chemical conditions in the water column. In 123 situ monitoring of water temperatures showed similar variations (between 14.7 and $24.6{ }^{\circ} \mathrm{C}$ ) in the 124 three artificial wetlands. Weekly measurements of specific conductivity, $\mathrm{pH}$, and dissolved oxygen 125 (DO) concentrations performed with a HQ40D multiparameter (HACH) also indicated comparable 126 values among artificial wetlands with mean ( \pm standard deviation) values of $337( \pm 13) \mu \mathrm{S} / \mathrm{cm}, 8.3$ $127( \pm 0.3)$, and $9.4( \pm 0.5) \mathrm{mg} / \mathrm{L}$ for specific conductivity, $\mathrm{pH}$ and $\mathrm{DO}$, respectively. Nutrient 128 concentrations were also measured weekly in the water column of the wetlands following Gette129 Bouvarot et al. (2014). Comparable dissolved nutrient concentrations and fluctuations were found 130 in the three wetlands with concentrations of $\mathrm{N}_{-} \mathrm{NO}_{3}{ }^{-}, \mathrm{N}_{-} \mathrm{NH}_{4}{ }^{+}$and $\mathrm{P}-\mathrm{PO}_{4}{ }^{3-}$ of $0.99 \pm 0.21$ (mean \pm $131 \mathrm{SD}) \mathrm{mg} / \mathrm{L}, 32.78 \pm 20.13 \mu \mathrm{g} / \mathrm{L}$ and $12.29 \pm 9.27 \mu \mathrm{g} / \mathrm{L}$, respectively. 
134 Biofilm and invertebrate samples were collected on the same day (October 22, 2014) to obtain a

135 data set linking benthic fauna with characteristics of the sedimentary biofilm. Analyses on benthic 136 samples were performed to determine biofilm characteristics (fluorescence measurements of 137 benthic algal biomass and composition, bacterial abundance, total organic carbon and total nitrogen 138 of the biofilm) and benthic communities of invertebrates. To facilitate the collection of benthic 139 samples, the water pumping into the study wetlands was stopped 2 days before the sampling date 140 to have between 30 and $40 \mathrm{~cm}$ of water level in all wetlands. In each wetland, we randomly selected 1416 replicate zones. For biofilm analyses, the top layer $(0-1 \mathrm{~cm})$ of sediments was cored in each zone 142 using cut syringes (internal diameter $=15 \mathrm{~mm}$ ). Fifteen samples were collected, mixed and 143 homogenized per zone to obtain representative sediment samples. For net photosynthetic activity 144 of the biofilm, analyses were performed on one intact core collected per zone. Benthic invertebrates 145 were sampled in each zone using a 200- $\mu$ m-mesh surber net following core collections for sediment 146 and biofilm analyses. The top sediment layer was collected on a surface of $150 \mathrm{~cm}^{2}$ per zone and

147 preserved with $96 \%$ ethanol. All samples were then stored at $\sim 10^{\circ} \mathrm{C}$ during transport to the 148 laboratory within 4 hours.

151 The biomass of green algae, diatoms and cyanobacteria at the water-sediment interface were 152 estimated by in situ measurements of chlorophyll- $a$ concentration and were expressed as 153 chlorophyll- $a$ equivalent per unit of surface. These measurements were performed with a benthic 154 fluorimetric probe (BenthoTorch, bbe Moldaenke GmbH) (see Harris and Graham 2015 for 155 details). 
156 The bacterial cell numbers were evaluated on sediment previously fixed with formaldehyde (final 157 concentration $2 \%$ v/v) by direct microscopy counts after incubation of the sediment with the Syto9 158 green fluorescent nucleic acid stain (Invitrogen). Details of the protocol were given in Gette159 Bouvarot et al. (2014). The total bacterial abundance (cells/g of dry sediment) was then determined.

161 Total organic carbon (TOC) and total nitrogen (TN) were measured as estimators of the 162 sedimentary biofilm biomass. Following Mermillod-Blondin et al. (2015), TOC and TN were 163 determined by high-temperature combustion of in situ pre-acidified $(\mathrm{HCl} 2 \mathrm{~N}$, to remove inorganic 164 carbon) dry samples $\left(60^{\circ} \mathrm{C}, 48 \mathrm{~h}\right)$ and subsequent measurements of $\mathrm{CO}_{2}$ and $\mathrm{N}_{2}$ by thermal 165 conductometry using an elemental analyzer (FlashEA 1112, Thermo Electron Corporation).

166 Net photosynthetic activity (NP) was determined by measuring oxygen production at $15^{\circ} \mathrm{C}$ (close 167 to field temperature at sampling date) on intact biofilms $\left(4 \mathrm{~cm}^{2}\right.$ collected with a cut syringe, see 168 above) using $4 \mathrm{~mL}$ respiration chambers fitted with micro-probes (Microrespiration system, 169 Unisense, see Gette-Bouvarot et al. 2015 for details). Photosynthesis measurements were 170 performed with an irradiance of $150 \mu \mathrm{mol} \cdot \mathrm{m}^{-2} \cdot \mathrm{s}^{-1}$, close to maximal photosynthetically active 171 radiations (PAR) measured at midday with a LI-193 Spherical Quantum Sensor (PAR varying 172 between 20 and $130 \mu \mathrm{mol} \mathrm{m} \mathrm{m}^{-2}$ depending on meteorological conditions). For measurements, 173 total dissolved inorganic carbon concentration was adjusted to $10 \mathrm{mM}$ with $\mathrm{KHCO}_{3}$ to ensure 174 sufficient supply of inorganic carbon during the incubation and $\mathrm{pH}$ was maintained at 6.5 by 175 addition of a citrate buffer. Net photosynthesis rate was expressed as nmol of $\mathrm{O}_{2} \cdot \mathrm{min}^{-1} \cdot \mathrm{cm}^{-2}$ of 176 sediment surface. 
179 Benthic invertebrates were collected by scraping a surface area of $150 \mathrm{~cm}^{2}$ with a surber net in each

180 sampled zone. Invertebrates were sorted and identified using Tachet et al. (2000) in the laboratory

181 using a stereomicroscope. All taxa were classified into seven trophic functional groups (grazers,

182 scrapers, deposit-feeders, filter-feeders, predators-parasites, detritivores and shredders) according

183 to their trophic affinities (Tachet et al. 2000). When one taxon was affiliated to 2 or more functional

184 groups, we applied a percentage of functional affinity in the abundance table for the given taxon

185 (i.e., $50 \%$ and $50 \%$ for one taxon affiliated to 2 functional groups).

186

187 Statistical analyses

188 One-way ANOVAs were performed to compare biofilm variables and the abundances and richness 189 (numbers of taxa) of each functional group of benthic invertebrates among wetlands. The 190 relationship between the biofilm table and the fauna table was evaluated by a co-inertia analysis

191 (see Dolédec and Chessel 1994; Dray et al. 2003). This multi-table analysis was performed to 192 examine the links between the two tables, each table using the same 18 samples as rows. The 193 relationship between each pair of data sets was measured using the Rv-coefficient (vectorial 194 correlation coefficient; Robert and Escoufier 1976). The $R v$-coefficient between two tables ranges 195 between 0 and 1 and is a multidimensional equivalent of the ordinary correlation coefficient 196 between two variables. For two given data sets $\mathrm{X}_{\mathrm{k}}$ and $\mathrm{X}_{1}$, the $R v$-coefficient writes as follows:

$$
R v\left(X_{k}, X_{l}\right)=\frac{\operatorname{Covv}\left(X_{k}, X_{l}\right)}{\sqrt{\operatorname{Vav}\left(X_{k}\right) \sqrt{\operatorname{Vav}\left(X_{l}\right)}}}
$$

198 with $\operatorname{Covv}\left(X_{k}, X_{l}\right)=\operatorname{Trace}\left(X_{k}^{t} D_{n} X_{l} D_{p}\right)$ as the vectorial covariance and $\operatorname{Vav}\left(X_{k}\right)=$ Trace $199\left(X_{k}^{t} D_{n} X_{k} D_{p}\right)$ and $\operatorname{Vav}\left(X_{l}\right)=$ Trace $\left(X_{l}^{t} D_{n} X_{l} D_{q}\right)$ as the vectorial variance for $X_{k}$ and $X_{l}$, 
respectively; Matrix $D_{n}$ contains row weights (common to both data sets) and matrices $D_{p}$ and $D_{q}$

201 contain the column weights of $X_{k}$ and $X_{1}$, respectively (see Blanc et al. 1998). To test the 202 significance of $R v$-coefficients, rows were randomly permutated within tables. Permutations were 203 repeated 1,000 times to obtain a null distribution of $R v$-coefficients. We assessed the statistical 204 significance by determining the proportion of null values that were greater than the observed $R v$ 205 coefficients.

206 Linear regressions were performed to determine the significance of the correlations among biofilm 207 characteristics and the abundance and richness of invertebrate functional groups (e.g., green algae 208 and grazer abundance). For all variables, the normality and the homoscedasticity of the residuals 209 were verified using the Shapiro-Wilk's test and the Levene's test, respectively. ANOVA analyses, 210 co-inertia analysis, linear regressions and graphical displays were performed using functions in the 211 ade4 package (Chessel et al. 2004; Dray et al. 2007) in R (R Development Core team 2015). 212 Significance for statistical tests was accepted for a first species risk $\alpha<0.05$.

$214 \underline{\text { Results }}$

216 Algal colonization of the water-sediment interface was significantly different among wetlands (Fig.

217 2) and followed the gradient of net productivity measured (Fig. 1): green algae and diatom 218 biomasses were positively correlated (Pearson's $r=0.829$ ) and exhibited decreasing values from 219 wetland A to wetland $\mathrm{C}$ with intermediate values in wetland B (one-way ANOVAs, $F_{2,15}=58.9, \mathrm{p}$ $220<0.001$ for green algae and $F_{2,15}=10.1, \mathrm{p}<0.01$ for diatoms). The densities of these two algal 221 groups were positively correlated with the net photosynthetic activity $\left(R^{2}=0.65, \mathrm{p}<0.001, \mathrm{n}=18\right.$ 
222 with green algae biomass, and $R^{2}=0.46, \mathrm{p}<0.01, \mathrm{n}=18$ with diatom biomass). Cyanobacteria

223 biomass showed a distinct pattern as it was significantly lower in wetland B than in the two other 224 wetlands (Fig. 2, one-way ANOVA, $F_{2,15}=79.4$, p $<0.001$ ). Percentages of total organic carbon 225 and total nitrogen were also the lowest at the sediment interface of wetland B (one-way ANOVAs, $226 F_{2,15}=5.1, \mathrm{p}<0.05$ for total organic carbon and $F_{2,15}=5.9, \mathrm{p}<0.05$ for total nitrogen). Hence, we 227 detected a significant and positive correlation between cyanobacteria biomass and total nitrogen $228\left(R^{2}=0.37, \mathrm{p}<0.01, \mathrm{n}=18\right)$ but not between cyanobacteria biomass and total organic carbon $\left(R^{2}\right.$ $229=0.18, \mathrm{p}>0.05, \mathrm{n}=18)$. In contrast, bacterial abundances were negatively correlated with 230 cyanobacteria biomasses $\left(R^{2}=0.55, \mathrm{p}<0.001, \mathrm{n}=18\right)$ and exhibited higher cell numbers in wetland B than in the other wetlands (one-way ANOVA, $F_{2,15}=14.6, \mathrm{p}<0.001$ ).

Functional composition of benthic invertebrate communities in the three wetlands

234 Abundances and richness of grazers and scrapers were significantly different among wetlands (one235 way ANOVAs, $F_{2,15}=14.1, \mathrm{p}<0.001$ for grazer abundance, $F_{2,15}=11.8, \mathrm{p}<0.001$ for scraper 236 abundance, $F_{2,15}=5.0, \mathrm{p}<0.05$ for grazer richness, and $F_{2,15}=15.3, \mathrm{p}<0.001$ for scraper richness).

237 Following the decreasing gradient of net productivity, they were the highest in wetland A and the 238 lowest in wetland C with intermediate values in wetland B (Fig. 3). The abundance of filter-feeders 239 tended to follow the same pattern with highest values in wetland A (Fig. 3, one-way ANOVA, $F_{2,15}$ $240=7.8, \mathrm{p}<0.01$ ) although filter-feeder richness did not vary significantly among wetlands (one-way 241 ANOVA, $F_{2,15}=1.7, \mathrm{p}>0.22$ ). Deposit-feeders exhibited a particular distribution compared with 242 grazers, scrapers and filter-feeders (Fig. 3). They were the most numerous in wetland B (one-way 243 ANOVA, $F_{2,15}=10.8, \mathrm{p}<0.01$ ) but their richness was low (between 1 and 2 taxa) and not 
244 significantly different among wetlands (one-way ANOVA, $F_{2,15}=2.5$, p $>0.1$ ). In contrast with

245 the other functional groups, the abundance and richness of predators were not significantly different 246 among wetlands (Fig. 3, one-way ANOVA, $F_{2,15}=2.4, \mathrm{p}>0.1$ for predator abundance and $F_{2,15}=$ $247 \quad 2.3, \mathrm{p}>0.15$ for predator richness).

Relationships between biofilm characteristics and functional composition of benthic invertebrate communities

250 The first two axis of co-inertia analysis explained more than $95 \%$ of the co-variation between 251 biofilm and fauna datasets and the structure shared by the two datasets was significantly different 252 from a structure expected from random association $(R v=0.60, \mathrm{p}<0.001)$. Samples were 253 discriminated among wetlands (Fig. 4A) and the short arrows displayed on Fig. 4A underlined the 254 good fit between biofilm and fauna datasets in the shared structure.

255 On the factorial map of variables (Fig. 4BC), the horizontal axis indicated that samples 256 characterized by high net photosynthetic activity and high diatom and green algae biomasses were 257 also dense and rich in herbivores (grazers and scrapers). There were significant positive linear 258 correlations between these biofilm characteristics (net photosynthetic activity, diatom or green 259 algae biomass) and the densities of herbivores (grazers and scrapers) (Fig. 5). The richness of 260 grazers and scrapers were also linearly and positively correlated with these biofilm characteristics 261 and more especially with the biomass of green algae (relationships illustrated on Fig. 6). The 262 vertical axis of the co-inertia analysis discriminated the samples with high bacterial densities and 263 high abundances of deposit feeders from those of high cyanobacteria biomass and nitrogen content 264 and low deposit-feeder abundances (Fig. 4BC). The abundance of deposit feeders was significantly 265 and positively correlated with bacterial abundance (Fig. 7A) but not with total nitrogen and total 
266 organic carbon $\left(R^{2}<0.1, \mathrm{p}>0.05, \mathrm{n}=18\right)$. The abundance of deposit feeders was negatively 267 correlated with cyanobacteria biomass (Fig. 7B). We did not detect clear correlations between 268 biofilm characteristics and the functional groups of filter feeders and predators. The abundance of 269 predators was significantly and positively correlated with the abundance of other invertebrates (Fig. 270 8). No significant correlations were obtained between predator richness and the abundance and 271 richness of other invertebrates.

\section{Discussion}

274 Although the literature highlighted the occurrence of significant top-down control of communities 275 in wetlands (Magnusson and Williams 2009; Hillebrand 2009; Moore 2018), top-down forces were 276 apparently weak in our systems. Then, our dataset did not corroborate the prediction of EEH

277 (Oksanen et al. 1981) suggesting a significant influence of top-down forces in our most productive 278 wetland. The analysis of the links between biofilms and functional trophic groups of invertebrates 279 clearly showed a dominant bottom-up effect of primary productivity (net photosynthesis) and algal resources on herbivores in artificial wetlands. Indeed, the abundances of both grazers and scrapers

281 were positively and linearly correlated with the biomass of green algae and diatoms in wetlands.

282 These correlations indicate that the bottom-up control of green algae and diatoms swamped out the 283 top-down influence of herbivores on algal resources. As previous enclosure experiments showed 284 that the introduction of a grazer (the gastropod Viviparus viviparus, a species which is not naturally 285 present in our artificial wetlands) had a significant top-down effect on algae in these artificial 286 wetlands (Gette-Bouvarot et al. 2015; Estragnat et al. 2018), we can conclude that pressure by 
grazers and scrapers naturally present in these systems was not sufficient enough to reduce algal

288 biomass.

289 Positive relationships between herbivore abundance and biomass of green algae and diatoms 290 contrasted with the lack of relationship detected between herbivores and cyanobacteria biomass.

291 This result may suggest that herbivores consumed green algae and diatoms rather than 292 cyanobacteria in wetlands, resulting in no relationship between cyanobacteria biomass and 293 herbivore abundance. This suggestion of a poor trophic transfer from cyanobacteria to herbivores 294 is consistent with several studies indicating that cyanobacteria are generally non-attractive trophic 295 sources for invertebrates due to their poor nutritional quality (low essential fatty acids and P 296 contents, Gulati and DeMott 1997; Paerl and Fulton 2006) and their chemical and structural defense 297 against grazing (DeMott et al. 1991; Soares et al. 2010; Bownik 2016). Our correlation analyses 298 also suggest that cyanobacteria had a negative influence on deposit-feeders. However, a toxic 299 impact of cyanobacteria on this functional group is highly improbable because examples of 300 negative interactions between cyanobacteria and deposit feeders in the field are lacking in the 301 literature and, in contrast, a study reported a positive effect of the fixation of $\mathrm{N}_{2}$ by cyanobacteria 302 on deposit feeders (Karlson et al. 2014). Moreover, we did not detect any negative influence of 303 cyanobacteria biomass on grazers and scrapers, two trophic functional groups that would be the 304 most affected by toxin produced by cyanobacteria (Bownik 2016). Together, these results suggest 305 that cyanobacteria were probably not toxic for invertebrates in our artificial wetlands.

306 In addition to the positive relationship between algal (green algae and diatoms) biomass and 307 herbivore abundances, we also showed that grazer and scraper richness were positively correlated 308 with the biomasses of green algae, diatoms and photosynthetic activity. These results indicate that 309 basal resources and net primary productivity may positively influence the horizontal diversity of 310 the food web (sensu Srivastava and Bell 2009). This positive relationship between primary 
311 productivity (and energy associated with trophic resources) and herbivore taxa richness can be

312 related to the "species-energy theory" (Wright 1983; Srivastava and Lawton 1998; Evans et al.

313 2005). Indeed, several studies support the hypothesis that energy correlates positively with species

314 richness (e.g, Huston 1994; Evans et al. 2005). In our field conditions, we can expect that an

315 increase in benthic primary productivity could have elevated the amount of certain individual

316 resource types (i.e., algal species), enabling specialist herbivore species to feed on them.

317 Consequently, this trophic specialization would have led to reduced niche overlap among

318 herbivores, reducing rates of competitive exclusion and elevating species richness in more

319 productive wetlands. We also suspect that the diversity of individual resource types (i.e., algal

320 species) increased with benthic primary productivity, enabling the highest herbivore diversity in

321 the wetland characterized by the highest algal richness. Nevertheless, we cannot confirm this

322 potential link between the trophic specialization of herbivore taxa and the abundances of individual

323 resource types because green algae and diatom groups contained several species with contrasted

324 trophic preferences for invertebrates (e.g., Tall et al. 2006; Alfaro 2009). More precise analyses

325 such as invertebrate gut analyses using metabarcoding approaches (Pompanon et al. 2012) would

326 be necessary to determine the trophic niche of each herbivore taxa in association with the

327 availability of algal species in artificial wetlands. This perspective is very promising to evaluate

328 whether the trophic specialization of herbivores in the most productive wetlands can explain the

329 positive relationship between net benthic primary productivity (energy) and herbivore taxa richness

330 in our artificial systems.

331 The positive and significant linear correlation between the abundances of predators and other 332 aquatic invertebrates also suggest that bottom-up control of predators by their prey blurred the top333 down control exerted by predators on their prey in our artificial wetlands. The lack of a strong top334 down control of invertebrate predators on other invertebrates in the most productive wetland 
335 (wetland A) would be associated with the increased horizontal diversity in food web observed for 336 grazers and scrapers in this wetland. Indeed, increased diversity of a trophic level would mitigate 337 top-down control by predators on this trophic level due to differences in predation pressure among 338 the species of this trophic level. More precisely, a resource base with more species is more likely 339 to contain at least one species that is relatively resistant to consumption and can compensate for 340 the decrease of more consumable species in the presence of consumers (Leibold 1989, Duffy et al. 341 2007). However, the mechanism responsible of the lack of top-down cascade in our artificial 342 wetlands is out of the scope of the present study. This further step would require more complete 343 description and quantification of species-species interactions within the food webs.

344 Considering the detritus-based food web, the positive linear relationship between the bacterial 345 abundance and the abundance of deposit-feeders suggests that the functional group of deposit346 feeders was also bottom-up controlled by their trophic resources. Nevertheless, the abundances of 347 bacteria and deposit-feeders were not correlated with the quantity of total organic carbon and total 348 nitrogen in the sediment. These results are not consistent with the positive relationship between 349 organic matter quantity and decomposer (micro- and macro-organisms) abundance classically 350 supporting the bottom-up theory in sedimentary environments (Dannovaro et al. 1995; Lin and Yo 351 2008; Ramalho et al. 2014). The positive link between bacteria and deposit-feeder abundance 352 observed in the present study was likely due to a positive influence of deposit-feeding activities on 353 bacteria, a process largely demonstrated in a wide range of freshwater sediments (van de Bund et 354 al. 1994; Griebler 1996; Traunspurger et al. 1997; Wieltschnig et al. 2008; Nogaro et al. 2009; 355 Pigneret et al. 2016). A recent experiment performed in one of the artificial infiltration wetlands 356 studied here demonstrated that aquatic oligochaetes, which are the main representatives of deposit357 feeders in the present study, had a strongly positive and significant influence on the abundance and 358 activity of bacteria in sediments (Mermillod-Blondin et al. 2018). More precisely, the bioturbation 
associated with the addition of the tubificid worm Limnodrilus hoffmeisteri increased the bacterial

360 abundance by 2 -fold and the microbial hydrolytic activity by $35 \%$ without influencing the quantity

361 of total nitrogen and organic carbon in sediments (Table 1). Thus, the top-down and positive effect

362 of deposit-feeders on micro-organisms was the most probable mechanism explaining the positive

363 relationship between bacteria and deposit-feeder abundances in the present experiment.

\section{Conclusions}

366 Our results did not corroborate the predictions of EEH suggesting that top-down controls would 367 have a significant influence on community structure in the most productive ecosystems. Indeed, a 368 dominance of bottom-up processes in the phototroph-based food web occurred in our artificial 369 wetlands whatever their productivity. Our strong linear correlations between the biomasses and 370 productivity of the algal component of the biofilm (especially green algae and diatoms) and the 371 abundances of grazers and scrapers suggest that algal biomass and benthic primary productivity 372 supported the herbivore trophic level. In contrast with the phototroph-based food web, results 373 obtained for the detritus-based food web illustrate a positive effect of deposit-feeding invertebrates 374 on bacteria. As observed in sedimentary environments with oligochaetes (Brinkhurst and Chua 375 1969; Wavre and Brinkhurst 1971; Fukuhara et al. 1980) and polychaetes (gardening effect, 376 Hylleberg 1975), the feeding activities of deposit-feeder such as aquatic oligochaetes might have 377 stimulated organic matter decomposition and bacterial growth in sediments. Thus, the present 378 experiment showed that phototroph-based and detritus-based food webs were not dominated by the 379 same processes in our artificial wetlands as herbivore abundance was likely controlled by the 380 biomass of basal resources (algae) whereas deposit-feeder abundance was not linked to the amount 381 of organic matter in sediments. Different feeding rates of invertebrates and contrasted renewal rate 
of basal resources (more rapid for algae than for detritic organic matter) between the two food webs may explain the different links between invertebrates and basal food sources reported for both food webs. These links are expected to have implications on the whole ecosystem functioning (nutrient cycling, energy fluxes) and need to be considered in future studies. With this aim, development of

386 labelling approaches using stable isotopes $-{ }^{13} \mathrm{C}$ and ${ }^{15} \mathrm{~N}$ - (Christianen et al. 2017) would be very 387 promising to precisely quantify the transfer of energy within the phototrophic-based and detritus388 based food webs and their consequences on ecosystem functioning. More research on artificial 389 wetlands is needed because these artificial systems have been increasingly developed to 390 compensate for the loss of natural wetlands, particularly in urbanized landscapes (Davidson 2014). 391 This is a major challenge for the future, considering the dramatic increase of the urbanization and 392 the role played by wetland ecosystems for biodiversity preservation and nutrient retention (Hanson 393 et al. 2005).

\section{Acknowledgments}

396 We would like to thank Félix Vallier for his help during laboratory analyses. This research was 397 done on the Research Platform of Crépieux-Charmy (Plate-forme de recherche de Crépieux398 Charmy) and received financial and technical support from the Urban Community of Lyon (Grand 399 Lyon La Métropole) and Veolia Water (Eau du Grand Lyon). This work was performed within the 400 framework of the EUR H2O'Lyon (ANR-17-EURE-0018) of Université de Lyon (UdL), within 401 the program "Investissements d'Avenir" operated by the French National Research Agency (ANR).

402 We also would like to thank the two anonymous referees for their pertinent comments that 403 significantly improved an earlier version of our manuscript. 
405 References

406 Alfaro AC (2009) Diet of the pulmonate gastropod Onchidella nigricans in the intertidal rocky 407 shore, New Zealand. Animal Biol 59:231-240.

408 Aunapuu M, Dahlgren J, Oksanen T, Grellmann D, Oksanen L, Olofsson J, Rammul U, Schneider 409 M, Johansen B, Hygen HO (2007) Spatial patterns and dynamic responses of arctic food 410 webs corroborate the exploitation ecosystems hypothesis (EEH). Am Nat 171:249-262.

411 Blanc L, Chessel D, Dolédec S (1998) Etude de la stabilité temporelle des structures spatiales par analyses d'une série de tableaux de relevés faunistiques totalement appariés. Bull Fr Pêche Pisc 348:1-21.

414 Bertness MD, Brisson CP, Bevil MC, Crotty SM (2014) Herbivory drives the spread of salt marsh 415 die-off. PLoS One 9(3):e92916.

416 Bownik A (2016) Harmful algae: Effects of cyanobacterial cyclic peptides on aquatic invertebratesa short review. Toxicon 124:26-35.

418 Brinkhurst RO, Chua KE (1969) Preliminary investigation of the exploitation of some potential 419 nutritional resources by three sympatric tubificid Oligochaetes. J Fish Res Bd Can 26:265968.

421 Chessel D, Dufour AB, Thioulouse J (2004) The ade4 package-I-One-table methods. R news 4: 5422 10. 
423

424

425

426

427

428

429

430

431

432

433

434

435

436

437

438

439

440

441

442

443

Christianen MJA, Middelburg JJ, Holthuijsen SJ, Jouta J, Compton TJ, Heide T, Piersma T, Damsté JSS, van der Veer HW, Schouten S, Olff H (2017) Benthic primary producers are key to sustain the Wadden Sea food web: stable carbon isotope analysis at landscape scale. Ecology 98:1498-1512.

Cobbaert D, Bayley SE, Greter JL (2010) Effects of a top invertebrate predator (Dytiscus alaskanus; Coleoptera: Dytiscidae) on fishless pond ecosystems. Hydrobiologia 644(1):103114.

Cummins KW, Klug MJ (1979) Feeding ecology of stream invertebrates. Ann Rev Ecol Syst 10:147-172.

Danovaro R, Della Croce N, Eleftheriou A, Fabiano M, Papadopoulou N, Smith C, Tselepides A (1995) Meiofauna of the deep Eastern Mediterranean Sea: distribution and abundance in relation to bacterial biomass, organic matter composition and other environmental factors. Prog Oceano 36:329-341.

Davidson NC (2014) How much wetland has the world lost? Long-term and recent trends in global wetland area. Mar. Freshwat Res 65:934-941.

De Meester L, Declerck S, Stoks R, Louette G, Van De Meutter F, De Bie T, Michels E, Brendonck L (2005) Ponds and pools as model systems in conservation biology, ecology and evolutionary biology. Aquatic conservation: Mar. Freshwat Ecosyst 15:715-725.

DeMott WR, Zhang QX, Carmichael WW (1991) Effects of toxic cyanobacteria and purified toxins on the survival and feeding of a copepod and three species of Daphnia. Limnol Oceano 36:1346-1357. 
444 Diehl S (1992) Fish predation and benthic community structure: the role of omnivory and habitat $445 \quad$ complexity. Ecology 73:1646-1661.

446 Dolédec S, Chessel D (1994) Co-inertia analysis: an alternative method for studying speciesenvironment relationships. Freshwat Biol 31:277-294.

Dray S, Chessel D, Thioulouse J (2003) Co-inertia analysis and the linking of ecological data tables. Ecology 84:3078-3089.

Dray S., Dufour AB, Chessel D (2007) The ade4 package-II: Two-table and K-table methods. R 451 news 7:47-52.

Du X., García-Berthou E., Wang Q., Liu J., Zhang T., Li Z. (2015) Analyzing the importance of top-down and bottom-up controls in food webs of Chinese lakes through structural equation modeling. Aquat Ecol 49:199-210.

Duffy JE, Cardinale BJ, France KE, McIntyre PB, Thébault E, Loreau M (2007) The functional role of biodiversity in ecosystems: incorporating trophic complexity. Ecology Lett 10:522-

Estragnat V, Mermillod-Blondin F, Jully M; Lemoine D; Lassabatere L; Volatier L (2018) Does 538. scale: a review of the mechanisms. Biol Rev 80:1-25. 
464 Foulquier A, Malard F, Mermillod-Blondin F, Montuelle B, Dolédec S, Volat B, Gibert J (2011)

465 Surface water linkages regulate trophic interactions in a groundwater food web. Ecosystems $466 \quad 14: 1339-1353$.

467 Fukuhara H, Kikuchi E, Kurihara Y (1980) The effects of Branchiura sowerbyi (Tubificidae) on 468 bacterial populations in submerged ricefield soil. Oikos 34:88-93.

469 Gette-Bouvarot M, Mermillod-Blondin F, Angulo-Jaramillo R, Delolme C, Lemoine D, 470 Lassabatere L, Loizeau S, Volatier L (2014) Coupling hydraulic and biological 471 measurements highlights the key influence of algal biofilm on infiltration basin performance. $472 \quad$ Ecohydrology 7:950-964.

473 Gette-Bouvarot M, Volatier L, Lassabatere L, Lemoine D, Simon L, Delolme C, Mermillod474 Blondin F (2015) Ecological engineering approaches to improve hydraulic properties of 475 infiltration basins designed for groundwater recharge. Env Sci Technol 49: 9936-9944.

476 Griebler C (1996) Some applications for the DMSO-reduction method as a new tool to determine the microbial activity in water-saturated sediments. Arch Hydrobiol Suppl 113:405-410.

478 Gruner DS, Smith JE, Seabloom EW, Sandin SA, Ngai JT, Hillebrand H, Harpole WS, Elser JJ, 479 Cleland EE, Bracken MES, Borer ET, Bolker BM (2008) A cross-system synthesis of 480 consumer and nutrient resource control on producer biomass. Ecol Lett 11:740-755. art, perspectives and priorities. Freshwat Biol 38:753-768. 
483

484

485

486

487

488

489

490

491

492

493

494

495

496

497

498

499

500

501

Hansson LA, Brönmark C, Anders Nilsson P, Åbjörnsson K (2005) Conflicting demands on wetland ecosystem services: nutrient retention, biodiversity or both? Freshwat Biol 50:705714.

Harris T, Graham J (2015) Preliminary evaluation of an in vivo fluorometer to quantify algal periphyton biomass and community composition. Lake Reserv Manag 31:127-133.

Hillebrand H (2009) Meta-analysis of grazer control of periphyton biomass across aquatic ecosystems. J Phycol 45:798-806.

Hoset KS, Ruffino L, Tuomi M, Oksanen T, Oksanen L, Mäkynen A, Johansen B, Moe T (2017) Changes in the spatial configuration and strength of trophic control across a productivity gradient during a massive rodent outbreak. Ecosystems 20:1421-35.

Hunter MD, Price PW (1992) Playing chutes and ladders: heterogeneity and the relative roles of bottom-up and top-down forces in natural communities. Ecology 73:724-732.

Huston MA (1994) Biological diversity: the coexistence of species. Cambridge University Press.

Hylleberg J (1975) Selective feeding by Abarenicola pacifica with notes on Abarenicola vagabunda and a concept of gardening in lugworms. Ophelia 14:113-137.

Karlson AM, Gorokhova E, Elmgren R (2014) Nitrogen fixed by cyanobacteria is utilized by deposit-feeders. PLoS One 9:e104460.

Laske SM, Rosenberger AE, Kane WJ, Wipfli MS, Zimmerman CE (2017) Top-down control of invertebrates by Ninespine Stickleback in Arctic ponds. Freshwat Sci 36:124-137. 
502

503

504

505

506

507

508

509

510

511

512

513

514

515

516

517

518

519

520

Leibold MA (1989) Resource edibility and the effects of predators and productivity on the outcome of trophic interactions. Am Nat 134:922-949.

Leibold MA, Chase JM, Shurin JB, Downing AL (1997) Species turnover and the regulation of trophic structure. Annu Rev Ecol Syst 28:467-494.

Lezama F, Baeza S, Altesor A, Cesa A, Chaneton EJ, Paruelo JM (2014) Variation of grazinginduced vegetation changes across a large-scale productivity gradient. J Veg Sci 25:8-21.

Lin KJ, Yo SP (2008) The effect of organic pollution on the abundance and distribution of aquatic oligochaetes in an urban water basin, Taiwan. Hydrobiologia 596:213-223.

Magnusson AK, Williams DD (2009) Top-down control by insect predators in an intermittent pond-a field experiment. Annal Limnol-Internat J Limnol 45:131-143.

Menge BA (2000) Top-down and bottom-up community regulation in marine rocky intertidal habitats. J Exp Mar Biol Ecol 250:257-289.

Menge BA, Olson AM, Dahlhoff EP (2002) Environmental stress, bottom-up effects, and community dynamics: integrating molecular-physiological and ecological approaches. Integr Compar Biol 42:892-908.

Mermillod-Blondin F, Simon L, Maazouzi C, Foulquier A, Delolme C, Marmonier P (2015) Dynamics of dissolved organic carbon (DOC) through stormwater basins designed for groundwater recharge in urban area: Assessment of retention efficiency. Water Res 81:2737. 
521 Mermillod-Blondin F, Bouvarot M, Déjollat Y, Adrien J, Maire E, Lemoine D, Marmonier P, $522 \quad$ Volatier L (2018) Influence of tubificid worms on sediment structure, benthic biofilm and 523 fauna in wetlands: A field enclosure experiment. Freshwat Biol 63:1420-1432.

524 Moore A (2018) Context-dependent consumer control in New England tidal wetlands. PloS One $525 \quad$ 13(5):e0197170.

526 Nogaro G, Mermillod-Blondin F, Valett MH, François-Carcaillet F, Gaudet J-P, Lafont M., Gibert 527 J (2009) Ecosystem engineering at the sediment-water interface: Bioturbation and consumer$528 \quad$ substrate interaction. Oecologia 161:125-138.

529 Odum EP, Smalley AE (1959) Comparison of population energy flow of an herbivorous and a 530 deposit-feeding invertebrate in a saltmarsh ecosystem. Proc Natl Acad Sci USA 45:617-622.

531 Oksanen L, Fretwell SD, Arruda J, Niemela P (1981) Exploitation ecosystems in gradients of 532 primary productivity. Am. Nat. 118:240-261.

Paerl HW, Fulton RS (2006) Ecology of harmful cyanobacteria. p. 95-109. In: E Granéli and JT 534 Turner [eds.], Ecology of harmful algae. Springer, Berlin, Heidelberg.

535 Pigneret M, Mermillod-Blondin F, Volatier L, Romestaing C, Maire E, Adrien J, Guillard L, 536 Tot Env 568:196-207. 846. 
541 Pompanon F, Deagle BE, Symondson WO, Brown DS, Jarman SN, Taberlet P (2012) Who is eating

542 what: diet assessment using next generation sequencing. Mol Ecol 21:1931-50.

543 Ramalho SP, Adão H, Kiriakoulakis K, Wolff GA, Vanreusel A, Ingels J (2014) Temporal and 544 spatial variation in the Nazaré Canyon (Western Iberian margin): Inter-annual and canyon 545 heterogeneity effects on meiofauna biomass and diversity. Deep Sea Res Part I: Oceano Res $546 \quad$ Papers 83:102-114.

547 Robert P, Escoufier Y (1976) A unifying tool for linear multivariate statistical methods: the RV$548 \quad$ coefficient. Appl Stat 25:257-265.

549 Sala NM, Bertness MD, Silliman B (2008) The dynamics of bottom-up and top-down control in a $550 \quad$ New England salt marsh. Oikos 117:1050-1056.

551 Shurin JB, Borer ET, Seabloom EW, Anderson K, Blanchette CA, Broitman B, Cooper SD, Halpern BS (2002) A cross-ecosystem comparison of the strength of trophic cascades. Ecol Lett 5:785-791.

554 Soares MCS, Lürling M, Huszar VL (2010) Responses of the rotifer Brachionus calyciflorus to 555 two tropical toxic cyanobacteria (Cylindrospermopsis raciborskii and Microcystis 556 aeruginosa) in pure and mixed diets with green algae. J Plankton Res 32:999-1008.

557 Srivastava DS, Bell T (2009) Reducing horizontal and vertical diversity in a foodweb triggers $558 \quad$ extinctions and impacts functions. Ecol Lett 12:1016-1028.

559 Srivastava DS, Lawton JH (1998) Why more productive sites have more species: an experimental 560 test of theory using tree-hole communities. Am Nat 152:510-529. 
561 Steiner CF (2001) The effects of prey heterogeneity and consumer identity on the limitation of $562 \quad$ trophic-level biomass. Ecology 82:2495-2506.

563 Sundbäck K, Miles A, Hulth S, Pihl L, Engström P, Selander E, Svenson A (2003) Importance of 564 benthic nutrient regeneration during initiation of macroalgal blooms in shallow bays. Mar $565 \quad$ Ecol Prog Ser 246:115-126.

566 Tachet H, Richoux P, Bournaud M, Usseglio-Polatera P (2000) Invertébrés d'eau douce: 567 systématique, biologie, écologie. CNRS éditions, Paris.

568 Tall L., Cattaneo A., Cloutier L., Dray S., Legendre P (2006) Resource partitioning in a grazer 569 guild feeding on a multilayer diatom mat. J North Am Benthol Soc 25:800-810.

570 Traunspurger W, Bergtold M, Goedkoop W (1997) The effects of nematodes on bacterial activity $571 \quad$ and abundance in a freshwater sediment. Oecologia 112:118-122.

572 Van de Bund WJ, Goedkoop W, Johnson RK (1994) Effects of deposit-feeder activity on bacterial 573 production and abundance in profundal Lake sediment. J North Am Benthol Soc 13:532-539.

574 Van de Koppel J, Herman PM, Thoolen P, Heip CH (2001) Do alternate stable states occur in 575 natural ecosystems? Evidence from a tidal flat. Ecology 82:3449-3461.

576 Watermann F, Hillebrand H, Gerdes G, Krumbein WE, Sommer U (1999) Competition between benthic cyanobacteria and diatoms as influenced by different grain sizes and temperatures.

Wavre M, Brinkhurst RO (1971) Interactions between some tubificid oligochaetes and bacteria 580 found in the sediments of Toronto Harbour, Ontario. J Fish Res Bd Can 28:335-341. 
581 Wieltschnig C, Fischer UR, Velimirov B, Kirschner AK (2008) Effects of deposit-feeding 582 macrofauna on benthic bacteria, viruses, and protozoa in a silty freshwater sediment. Microb $583 \quad$ Ecol 56:1-12.

584 Wright DH (1983) Species-energy theory: an extension of species-area theory. Oikos 41:496-506. 
Figure legends:

587 Fig 1: Percentage of fine particles $(<63 \mu \mathrm{m})$, benthic algal biomass and net photosynthetic activity 588 of benthic biofilms measured in the three studied wetlands ( $n=6$ measures per wetland).

589 Fig 2: Characteristics of the biofilms in the three wetlands $(n=6$ measures per wetland for each 590 variable).

591 Fig 3: Abundances (ind $/ \mathrm{m}^{2}$ ) and richness (taxa/sample) of the five major trophic functional groups 592 of benthic invertebrates collected in the three wetlands ( $\mathrm{n}=6$ measures per wetland).

593 Fig 4: Co-inertia analysis showing a) the shared structure obtained from the biofilm and fauna 594 datasets, b) the factorial map of biofilm variables and c) the factorial map of variables associated 595 with invertebrate functional groups. $\mathrm{A}=$ Wetland $\mathrm{A}, \mathrm{B}=$ Wetland $\mathrm{B}, \mathrm{C}=$ Wetland $\mathrm{C}$, PhotoS $=$ Net 596 Photosynthesis rate, $\mathrm{TOC}=\mathrm{Total}$ organic carbon, $\mathrm{TN}=$ Total nitrogen, Deposit $\mathrm{AB}=$ Abundances 597 of deposit feeders, DepositRICH $=$ Richness of deposit feeders, ScrapAB $=$ Abundances of 598 scrapers, ScrapRICH $=$ Richness of scrapers, FiltAB $=$ Abundances of filter-feeders, FiltRICH $=$ 599 Richness of filter-feeders, GrazerAB = Abundances of grazers, GrazerRICH = Richness of grazers, 600 Pred $\mathrm{AB}=$ Abundances of predators, PredRICH $=$ Richness of predators.

601 Fig 5: Correlations a) between net photosynthetic activity and grazer abundance, b) between net 602 photosynthetic activity and scraper abundance, c) between green algae biomass and grazer 603 abundance, d) between green algae biomass and scraper abundance, e) between diatom biomass 604 and grazer abundance, and f) between diatom biomass and scraper abundance.

605 Fig 6: Correlations a) between green algae biomass and grazer richness and b) between green algae 606 biomass and scraper richness. 
607 Fig 7: Correlations a) between bacterial abundance and deposit-feeder abundance, and b) between 608 cyanobacteria biomass and deposit-feeder abundance.

609 Fig 8: Correlation between predator abundance and the abundance of other invertebrates.

610 

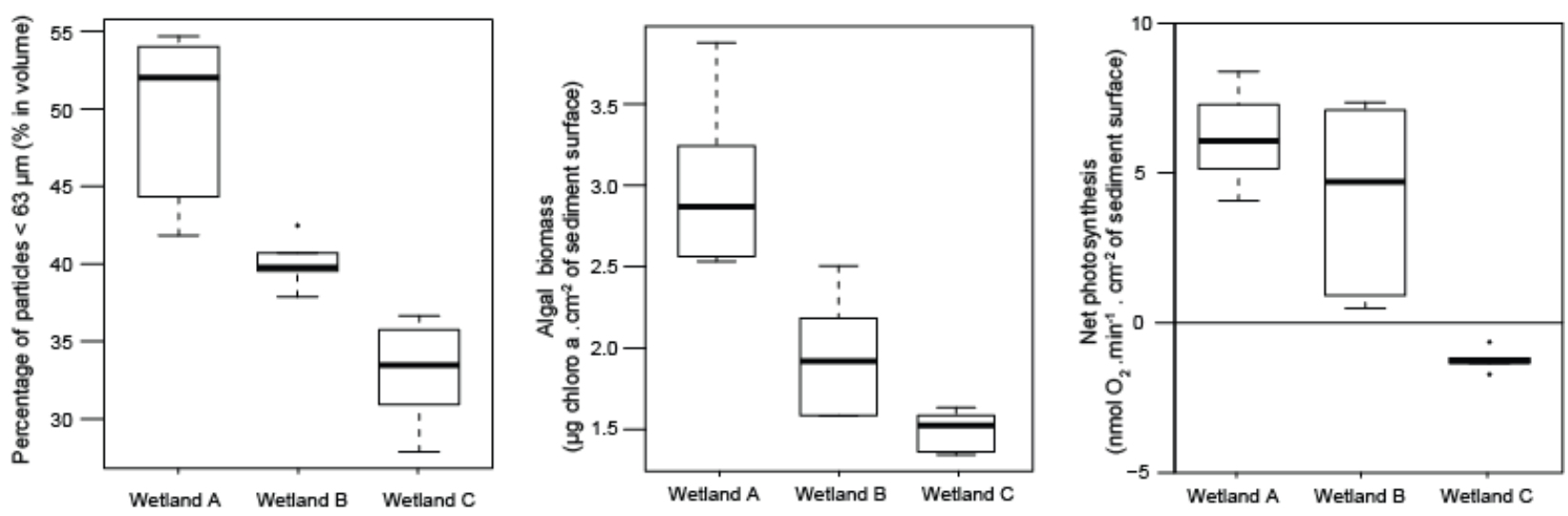

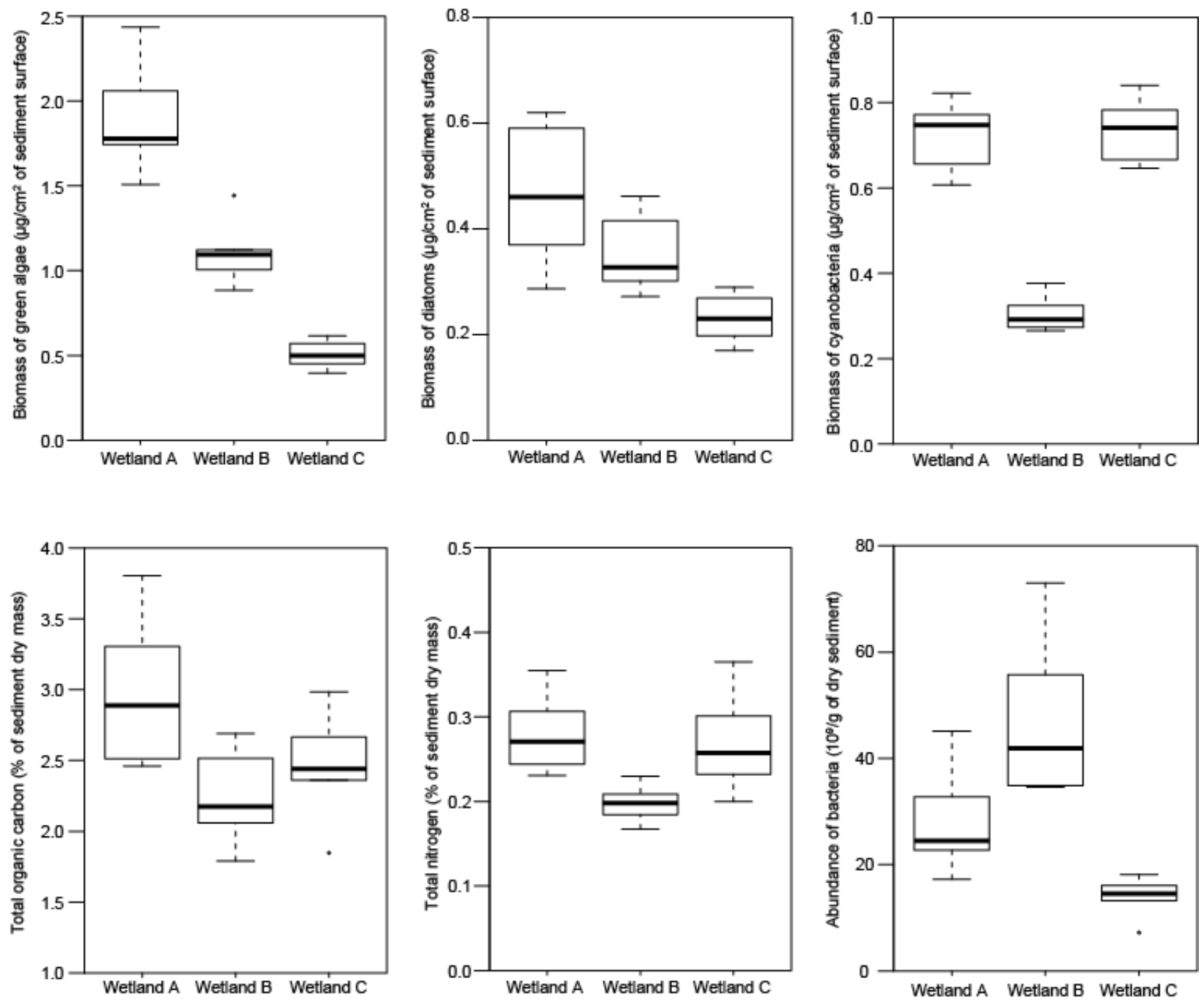

Fig 2 

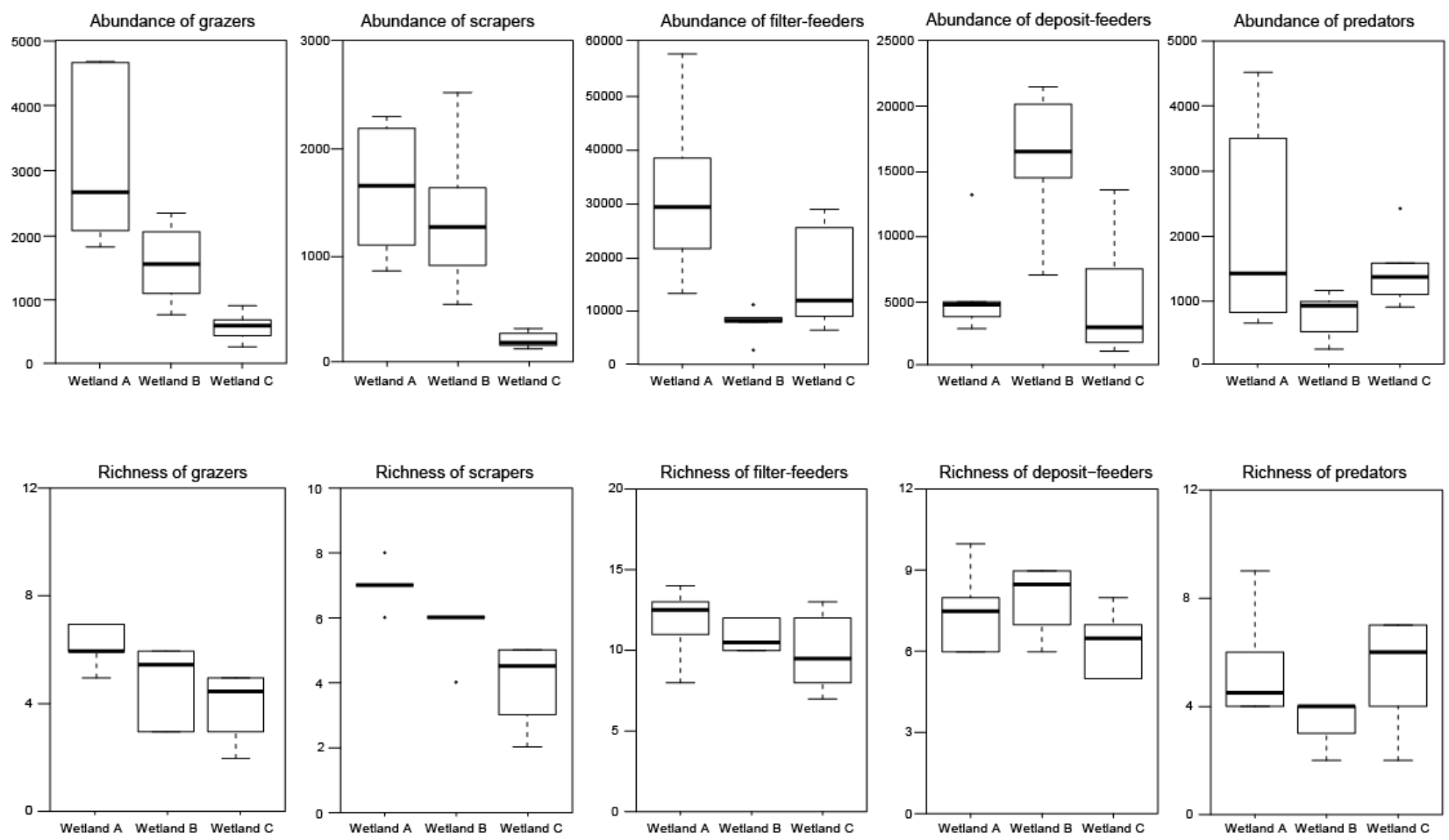


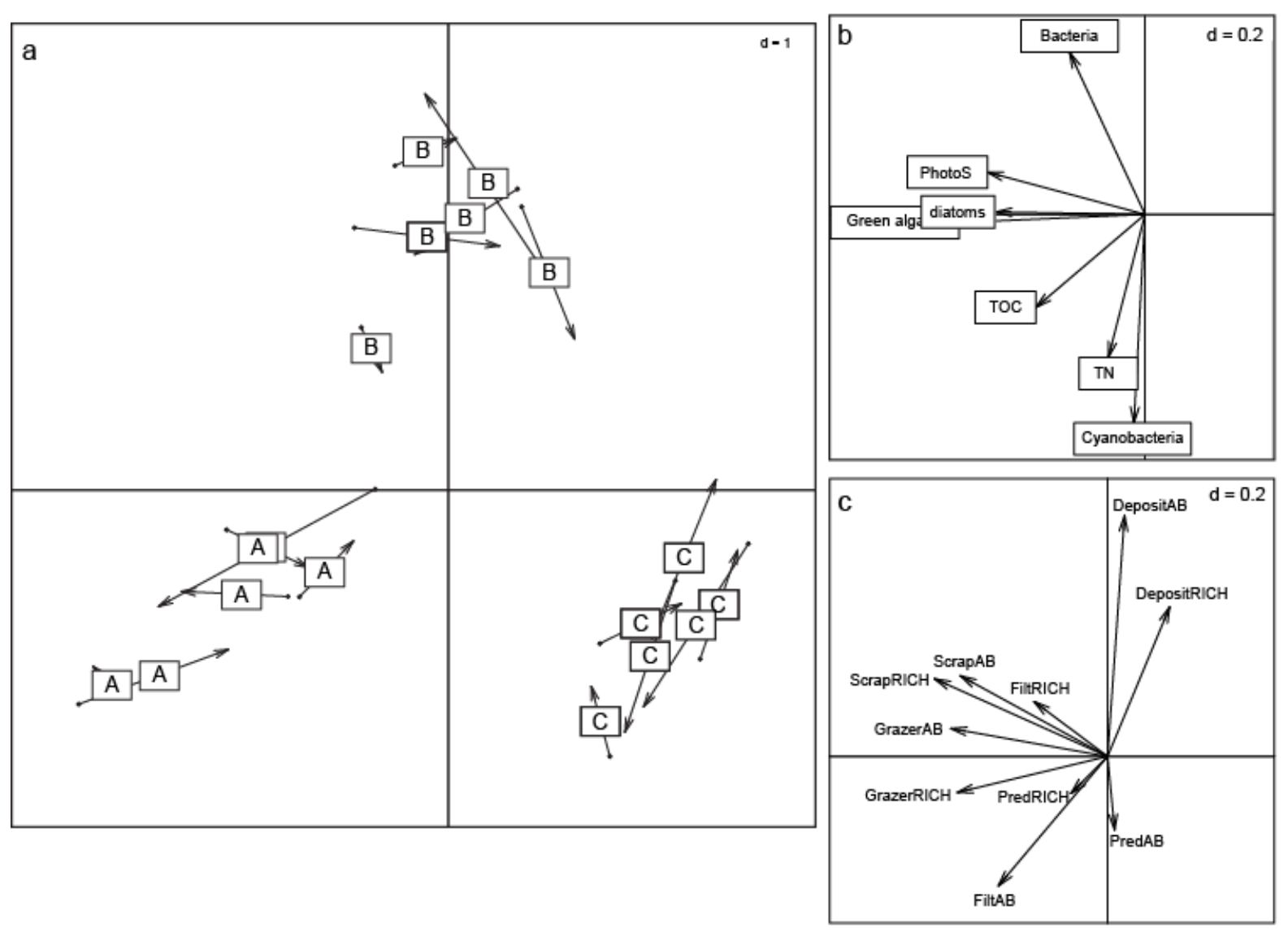


a

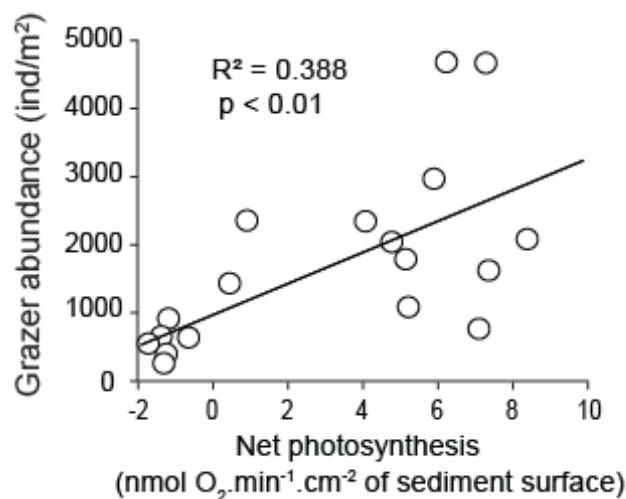

(nmol O $2 \cdot \mathrm{min}^{-1} \cdot \mathrm{cm}^{-2}$ of sediment surface)
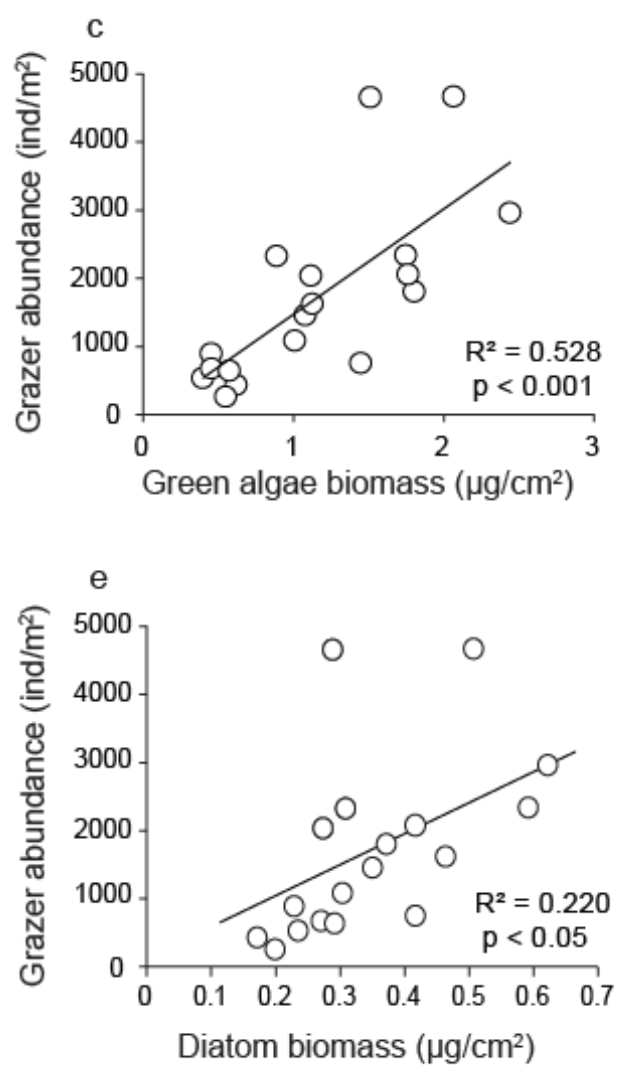

b

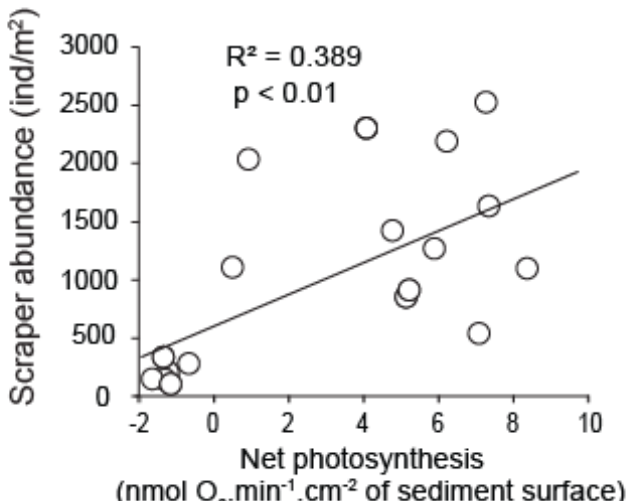

${ }_{2} \cdot \mathrm{min}^{-1} \cdot \mathrm{cm}^{-2}$ of sediment surface)
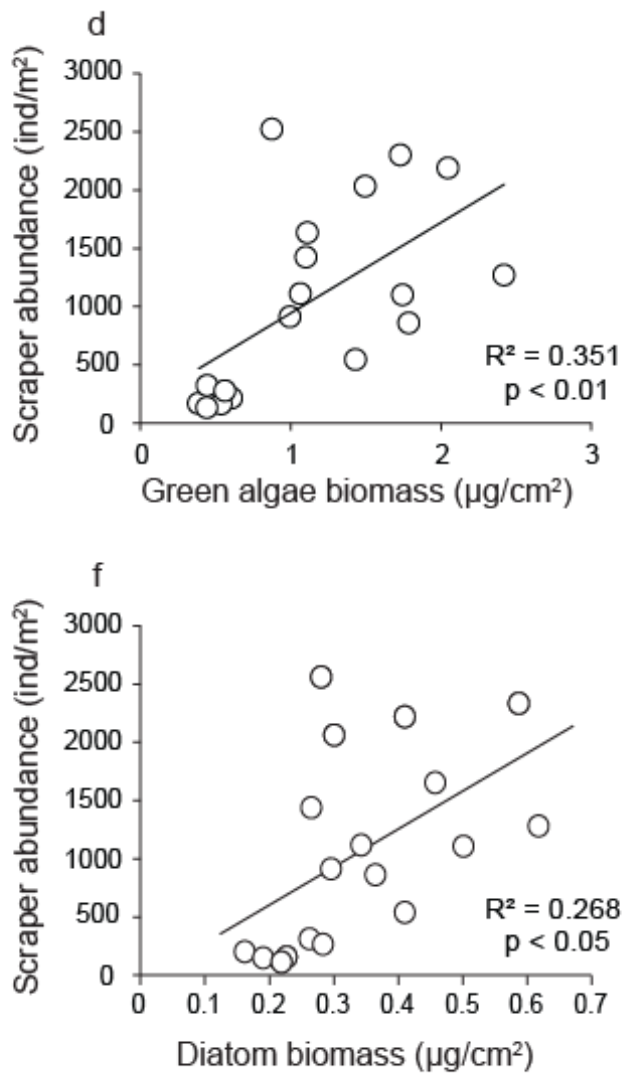

Fig 5 

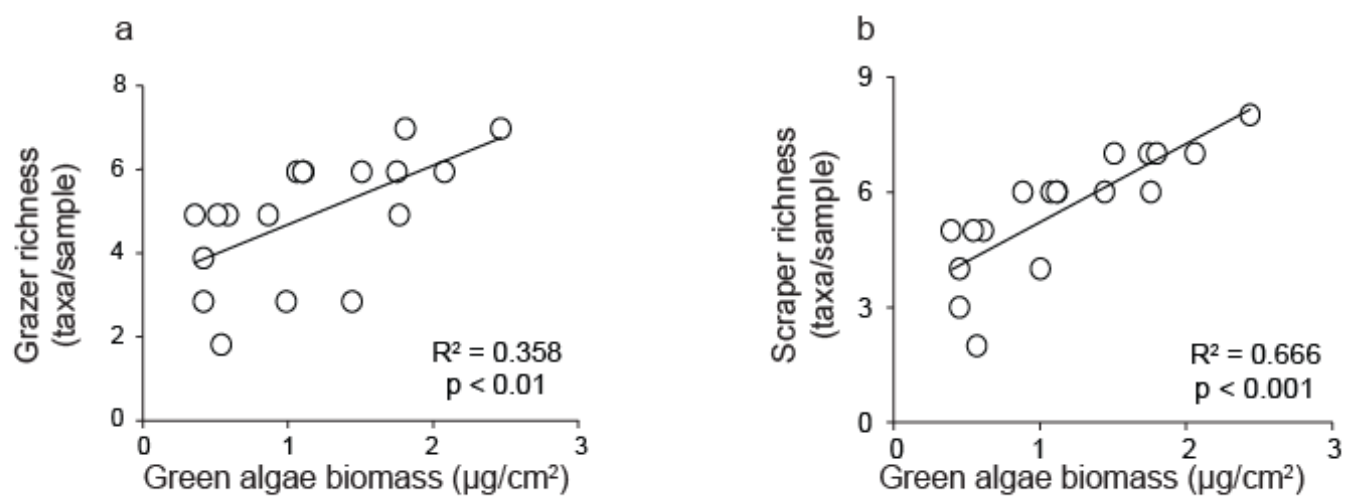

Fig 6 

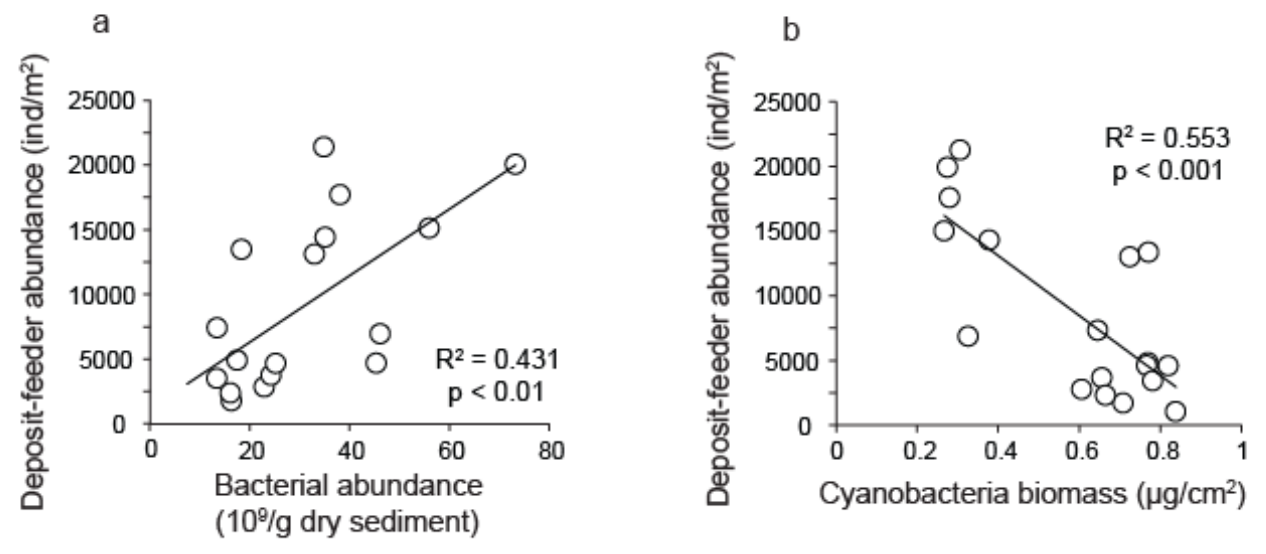

Fig 7 


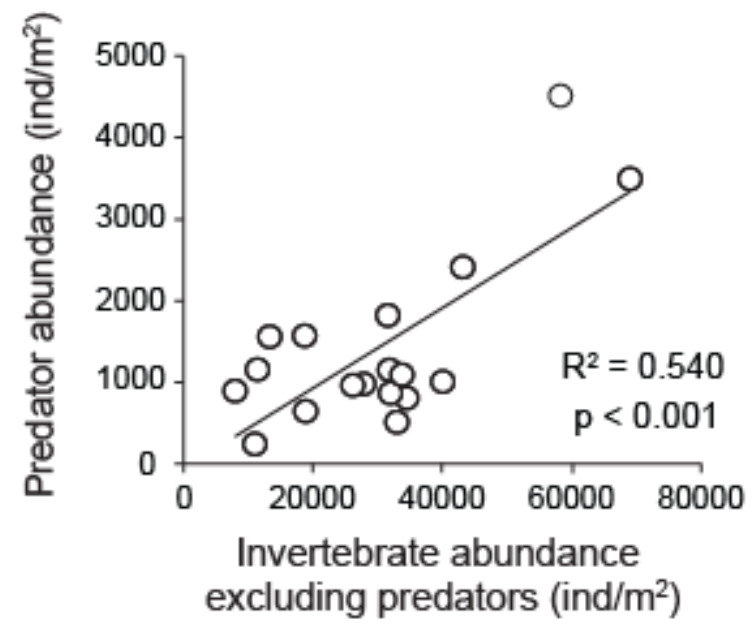


630 Table 1. Mean values $( \pm \mathrm{SD})$ of the biofilm variables measured in 6 enclosures without worms and 6316 enclosures in which a density of 20,000 individuals $\mathrm{m}^{-2}$ of the tubificid worm L. hoffmeisteri has 632 been added. Student-t tests were run to evaluate the influence of tubificid worm addition on biofilm 633 variables. Modified from Mermillod-Blondin et al. (2018)

\begin{tabular}{|c|c|c|c|c|}
\hline Measured variables & $\begin{array}{l}\text { Control enclosures } \\
\text { averaged values } \pm \\
\text { standard deviation } \\
\end{array}$ & $\begin{array}{l}\text { Worm enclosures } \\
\text { averaged values } \pm \\
\text { standard deviation } \\
\end{array}$ & $\mathrm{t}_{(10,0.05)}$ & $p$-values \\
\hline $\begin{array}{l}\text { Bacterial cells } \\
\left(10^{9} / \mathrm{g} \text { of dry sediment }\right)\end{array}$ & $3.20 \pm 1.05$ & $6.48 \pm 1.90$ & 4.04 & 0.002 \\
\hline $\begin{array}{l}\text { Total organic carbon } \\
\text { (\% of dry sediment) }\end{array}$ & $0.788 \pm 0.424$ & $0.704 \pm 0.268$ & 0.41 & 0.689 \\
\hline $\begin{array}{l}\text { Total nitrogen } \\
\text { (\% of dry sediment) }\end{array}$ & $0.117 \pm 0.056$ & $0.112 \pm 0.034$ & 0.19 & 0.857 \\
\hline $\begin{array}{l}\text { Hydrolytic activity } \\
\left(10^{-2} \mu \text { mol of hydrolyzed FDA }\right. \\
\left.. \mathrm{h}^{-1} \cdot \mathrm{g}^{-1} \text { of dry sediment }\right)\end{array}$ & $4.57 \pm 1.00$ & $6.16 \pm 0.84$ & 2.99 & 0.013 \\
\hline
\end{tabular}


638 Supplementary Material 1: Table of taxa abundances for each sample (sampled surface: $150 \mathrm{~cm}^{2}$ ). 639 The last column indicates the affiliation of taxa to functional groups. G: Grazers, S: Scrapers, DF: 640 Deposit-feeders, F: filter-feeders, P: predators and parasites, D: Detritivores, and Shr: Shredders.

\begin{tabular}{|c|c|c|c|c|c|c|c|}
\hline \multirow[b]{2}{*}{ Taxa } & \multirow[b]{2}{*}{$\mathrm{A}$} & \multirow[b]{2}{*}{ A } & \multicolumn{2}{|c|}{ Sampled basin } & \multirow[b]{2}{*}{$\mathrm{A}$} & \multirow[b]{2}{*}{ A } & \multirow[b]{2}{*}{ Feeding groups } \\
\hline & & & $\mathrm{A}$ & $\mathrm{A}$ & & & \\
\hline Naidinae sp. & 35 & 32 & 47 & 57 & 56 & 104 & $\mathrm{G} / \mathrm{S}$ \\
\hline other oligochaetes & 30 & 13 & 7 & 8 & 8 & 8 & $\mathrm{G} / \mathrm{S}$ \\
\hline Enchytraeidae & 116 & 82 & 127 & 235 & 464 & 104 & DF \\
\hline Hydra sp. & 54 & 6 & 32 & 27 & 24 & 152 & $\mathrm{P}$ \\
\hline Dugesia spp. & 4 & 0 & 0 & 1 & 8 & 0 & $\mathrm{P}$ \\
\hline Nematoda & 98 & 63 & 58 & 36 & 568 & 168 & $\mathrm{P} / \mathrm{DF}$ \\
\hline Erpobdella sp. & 0 & 0 & 0 & 0 & 0 & 0 & $\mathrm{P}$ \\
\hline Physa acuta + Physa fontinalis & 7 & 5 & 2 & 4 & 8 & 0 & $\mathrm{G} / \mathrm{S}$ \\
\hline Galba truncatula & 161 & 45 & 44 & 40 & 168 & 88 & $\mathrm{G} / \mathrm{S}$ \\
\hline Gyraulus sp. & 0 & 0 & 0 & 2 & 0 & 8 & $\mathrm{G} / \mathrm{S}$ \\
\hline Hydracarina & 0 & 0 & 0 & 1 & 0 & 0 & $\mathrm{P}$ \\
\hline Cyclopoida & 721 & 277 & 740 & 524 & 1048 & 1624 & $\mathrm{~F}$ \\
\hline Calanoida & 0 & 0 & 0 & 0 & 0 & 0 & $\mathrm{~F}$ \\
\hline Harpaticoida & 0 & 2 & 0 & 0 & 0 & 0 & B \\
\hline Chidorus sphaericus + Chidorus sp. & 14 & 0 & 120 & 0 & 145 & 94 & $\mathrm{~F}$ \\
\hline Eurycercus lamellatus & 95 & 40 & 150 & 137 & 181 & 188 & $\mathrm{~F}$ \\
\hline Sida crystallina & 27 & 26 & 180 & 0 & 0 & 141 & $\mathrm{~F}$ \\
\hline Simocephalus vetulus & 191 & 40 & 120 & 0 & 36 & 423 & $\mathrm{~F}$ \\
\hline Simocephalus expinosus & 109 & 92 & 209 & 137 & 508 & 470 & $\mathrm{~F}$ \\
\hline Simocephalus sp. & 0 & 13 & 60 & 55 & 36 & 0 & $\mathrm{~F}$ \\
\hline Alona quadrangularis & 82 & 0 & 30 & 0 & 109 & 141 & $\mathrm{~F}$ \\
\hline Pleuroxus sp. & 14 & 0 & 0 & 0 & 36 & 0 & $\mathrm{~F}$ \\
\hline Acroperus harpae & 0 & 13 & 0 & 0 & 36 & 0 & $\mathrm{~F}$ \\
\hline Daphnia pulex & 123 & 357 & 568 & 906 & 290 & 800 & $\mathrm{~F}$ \\
\hline Non identified cladocera + other Daphnia & 14 & 0 & 60 & 0 & 109 & 94 & $\mathrm{~F}$ \\
\hline Pseudocandona albicans & 0 & 0 & 0 & 1 & 0 & 0 & DF \\
\hline Ilyocypris bradyi & 0 & 0 & 0 & 1 & 0 & 0 & DF \\
\hline Heterocypris salina & 4 & 2 & 0 & 4 & 0 & 0 & DF \\
\hline
\end{tabular}


Sampled basin

\begin{tabular}{|l|c|c|c|c|c|c|c|}
\hline & A & A & A & A & A & A & Feeding groups \\
\hline Cypridopsis vidua & 20 & 1 & 0 & 9 & 0 & 8 & DF \\
\hline Bradleystrandesia obliqua & 22 & 6 & 8 & 7 & 16 & 0 & F \\
\hline Limmocythere inopinata & 0 & 0 & 0 & 0 & 0 & 0 & DF \\
\hline Gammarus sp. & 1 & 0 & 0 & 0 & 0 & 0 & Shr/P \\
\hline Cloeon sp. & 43 & 76 & 95 & 152 & 208 & 224 & B \\
\hline Caenis sp. & 0 & 0 & 0 & 0 & 0 & 0 & Shr/D \\
\hline Hydroptilidae agrayla & 11 & 3 & 0 & 3 & 2 & 4 & G/S \\
\hline Haliplidae haliplus & 6 & 6 & 0 & 4 & 1 & 0 & Shr \\
\hline Gyrinidae gyrinus + Hydrophilidae berosus + Elmidae esolus & 1 & 1 & 0 & 0 & 0 & 0 & P \\
\hline Chironomidae Tanytarsini & 145 & 108 & 116 & 48 & 264 & 112 & F/DF \\
\hline Chironomidae Chironominae & 85 & 31 & 41 & 6 & 48 & 56 & F/DF \\
\hline Chironomidae Orthocladinae & 58 & 18 & 33 & 50 & 32 & 88 & R/DF \\
\hline Chironomidae Tanypodinae & 11 & 7 & 9 & 0 & 0 & 8 & \\
\hline Nymphs of chironomidae & 44 & 8 & 43 & 29 & 24 & 16 & P/F/DF/S \\
\hline Chaoborus sp. & 1 & 0 & 0 & 0 & 0 & 0 & P \\
\hline Ceratopogoninae & 2 & 0 & 0 & 3 & 0 & 0 & \\
\hline Dasyhelinae & 0 & 0 & 0 & 3 & 1 & 3 \\
\hline Other diptera & 3 & 0 & 0 & 6 & 1 & D \\
\hline Libellulidae + Sympetrinae + Plactycnemididae & 5 & 0 & 1 & 4 & 2 & 0 \\
\hline
\end{tabular}




\begin{tabular}{|c|c|c|c|c|c|c|c|}
\hline \multirow[b]{2}{*}{ Taxa } & \multirow[b]{2}{*}{$\mathrm{B}$} & \multirow[b]{2}{*}{$\mathrm{B}$} & \multicolumn{2}{|c|}{ Sampled basin } & \multirow[b]{2}{*}{$\mathrm{B}$} & \multirow[b]{2}{*}{$\mathrm{B}$} & \multirow[b]{2}{*}{ Feeding groups } \\
\hline & & & $\mathrm{B}$ & $\mathrm{B}$ & & & \\
\hline Naidinae sp. & 64 & 40 & 87 & 53 & 60 & 23 & $\mathrm{G} / \mathrm{S}$ \\
\hline other oligochaetes & 32 & 0 & 1 & 0 & 10 & 3 & $\mathrm{G} / \mathrm{S}$ \\
\hline Enchytraeidae & 640 & 1000 & 1289 & 699 & 1191 & 415 & DF \\
\hline Hydra sp. & 0 & 0 & 1 & 0 & 4 & 0 & $\mathrm{P}$ \\
\hline Dugesia spp. & 0 & 0 & 4 & 0 & 0 & 0 & $\mathrm{P}$ \\
\hline Nematoda & 128 & 128 & 50 & 102 & 104 & 18 & P/DF \\
\hline Erpobdella sp. & 0 & 0 & 0 & 0 & 0 & 0 & $P$ \\
\hline Physa acuta + Physa fontinalis & 8 & 0 & 2 & 1 & 2 & 0 & $\mathrm{G} / \mathrm{S}$ \\
\hline Galba truncatula & 160 & 64 & 43 & 131 & 104 & 40 & $\mathrm{G} / \mathrm{S}$ \\
\hline Gyraulus sp. & 0 & 0 & 0 & 0 & 0 & 0 & $\mathrm{G} / \mathrm{S}$ \\
\hline Hydracarina & 0 & 0 & 0 & 0 & 0 & 1 & $\mathrm{P}$ \\
\hline Cyclopoida & 312 & 248 & 238 & 219 & 200 & 68 & $\mathrm{~F}$ \\
\hline Calanoida & 0 & 0 & 0 & 0 & 0 & 0 & $\mathrm{~F}$ \\
\hline Harpaticoida & 0 & 0 & 2 & 2 & 0 & 0 & B \\
\hline Chidorus sphaericus + Chidorus sp. & 38 & 25 & 0 & 14 & 48 & 7 & $\mathrm{~F}$ \\
\hline Eurycercus lamellatus & 19 & 0 & 39 & 12 & 12 & 3 & $\mathrm{~F}$ \\
\hline Sida crystallina & 19 & 25 & 65 & 16 & 83 & 13 & $\mathrm{~F}$ \\
\hline Simocephalus vetulus & 0 & 0 & 45 & 16 & 24 & 6 & $\mathrm{~F}$ \\
\hline Simocephalus expinosus & 29 & 62 & 39 & 0 & 12 & 14 & $\mathrm{~F}$ \\
\hline Simocephalus sp. & 0 & 0 & 0 & 0 & 0 & 1 & $\mathrm{~F}$ \\
\hline Alona quadrangularis & 19 & 25 & 0 & 21 & 24 & 10 & $\mathrm{~F}$ \\
\hline Pleuroxus sp. & 0 & 0 & 0 & 0 & 0 & 2 & $\mathrm{~F}$ \\
\hline Acroperus harpae & 29 & 0 & 0 & 5 & 0 & 0 & $\mathrm{~F}$ \\
\hline Daphnia pulex & 0 & 12 & 13 & 21 & 0 & 0 & $\mathrm{~F}$ \\
\hline Non identified cladocera + other Daphnia & 0 & 12 & 0 & 11 & 12 & 0 & $\mathrm{~F}$ \\
\hline Pseudocandona albicans & 0 & 0 & 11 & 2 & 1 & 0 & DF \\
\hline Ilyocypris bradyi & 0 & 8 & 0 & 3 & 2 & 0 & DF \\
\hline Heterocypris salina & 0 & 0 & 0 & 0 & 0 & 0 & DF \\
\hline
\end{tabular}




\begin{tabular}{|c|c|c|c|c|c|c|c|}
\hline \multirow[b]{2}{*}{ Taxa } & \multirow[b]{2}{*}{ B } & \multirow[b]{2}{*}{ B } & \multicolumn{2}{|c|}{ Sampled basin } & \multirow[b]{2}{*}{ B } & \multirow[b]{2}{*}{ B } & \multirow[b]{2}{*}{ Feeding groups } \\
\hline & & & $\mathrm{B}$ & $\mathrm{B}$ & & & \\
\hline Cypridopsis vidua & 0 & 24 & 6 & 11 & 5 & 0 & $\mathrm{DF}$ \\
\hline Bradleystrandesia obliqua & 37 & 16 & 9 & 14 & 9 & 0 & $\mathrm{~F}$ \\
\hline Limmocythere inopinata & 19 & 0 & 2 & 0 & 0 & 0 & DF \\
\hline Gammarus sp. & 0 & 0 & 0 & 0 & 0 & 0 & Shr/P \\
\hline Cloeon sp. & 32 & 24 & 34 & 18 & 55 & 19 & $\mathrm{~B}$ \\
\hline Caenis sp. & 0 & 0 & 3 & 1 & 0 & 0 & Shr/D \\
\hline Hydroptilidae agrayla & 0 & 0 & 0 & 3 & 1 & 1 & $\mathrm{G} / \mathrm{S}$ \\
\hline Haliplidae haliplus & 4 & 0 & 4 & 7 & 9 & 1 & Shr \\
\hline Gyrinidae gyrinus + Hydrophilidae berosus + Elmidae esol & 1 & 0 & 0 & 0 & 0 & 0 & $\mathrm{P}$ \\
\hline Chironomidae Tanytarsini & 464 & 243 & 210 & 292 & 177 & 65 & F/DF \\
\hline Chironomidae Chironominae & 137 & 46 & 131 & 171 & 135 & 56 & F/DF \\
\hline Chironomidae Orthocladinae & 61 & 21 & 15 & 35 & 15 & 7 & $\mathrm{R} / \mathrm{DF}$ \\
\hline Chironomidae Tanypodinae & 15 & 5 & 3 & 14 & 4 & 7 & $\mathrm{P}$ \\
\hline Nymphs of chironomidae & 61 & 5 & 15 & 13 & 16 & 3 & $\mathrm{P} / \mathrm{F} / \mathrm{DF} / \mathrm{S}$ \\
\hline Chaoborus sp. & 0 & 0 & 0 & 0 & 0 & 0 & $\mathrm{P}$ \\
\hline Ceratopogoninae & 0 & 0 & 0 & 1 & 0 & 0 & D \\
\hline Dasyhelinae & 0 & 0 & 0 & 0 & 0 & 0 & $\mathrm{D}$ \\
\hline Other diptera & 1 & 0 & 0 & 1 & 0 & 0 & $\mathrm{P}$ \\
\hline Libellulidae + Sympetrinae + Plactycnemididae & 0 & 0 & 3 & 2 & 1 & 0 & $\mathrm{P}$ \\
\hline
\end{tabular}




\begin{tabular}{|c|c|c|c|c|c|c|c|}
\hline \multirow[b]{2}{*}{ Taxa } & \multirow[b]{2}{*}{$\mathrm{C}$} & \multirow[b]{2}{*}{$\mathrm{C}$} & \multicolumn{2}{|c|}{ Sampled basin } & \multirow[b]{2}{*}{$\mathrm{C}$} & \multirow[b]{2}{*}{$\mathrm{C}$} & \multirow[b]{2}{*}{ Feeding groups } \\
\hline & & & C & $\mathrm{C}$ & & & \\
\hline Naidinae sp. & 4 & 1 & 1 & 0 & 0 & 0 & $\mathrm{G} / \mathrm{S}$ \\
\hline other oligochaetes & 0 & 3 & 0 & 0 & 8 & 0 & $\mathrm{G} / \mathrm{S}$ \\
\hline Enchytraeidae & 16 & 13 & 101 & 28 & 432 & 724 & DF \\
\hline Hydra sp. & 1 & 0 & 0 & 2 & 0 & 0 & $\mathrm{P}$ \\
\hline Dugesia spp. & 0 & 0 & 0 & 0 & 0 & 0 & $\mathrm{P}$ \\
\hline Nematoda & 149 & 115 & 198 & 202 & 152 & 331 & $\mathrm{P} / \mathrm{DF}$ \\
\hline Erpobdella sp. & 0 & 1 & 0 & 1 & 0 & 0 & $\mathrm{P}$ \\
\hline Physa acuta + Physa fontinalis & 4 & 3 & 1 & 8 & 0 & 0 & $\mathrm{G} / \mathrm{S}$ \\
\hline Galba truncatula & 19 & 14 & 17 & 7 & 32 & 37 & $\mathrm{G} / \mathrm{S}$ \\
\hline Gyraulus sp. & 1 & 0 & 0 & 0 & 0 & 0 & $\mathrm{G} / \mathrm{S}$ \\
\hline Hydracarina & 0 & 1 & 1 & 0 & 0 & 1 & $\mathrm{P}$ \\
\hline Cyclopoida & 115 & 42 & 48 & 168 & 96 & 266 & $\mathrm{~F}$ \\
\hline Calanoida & 28 & 15 & 71 & 76 & 272 & 208 & $\mathrm{~F}$ \\
\hline Harpaticoida & 0 & 0 & 0 & 1 & 0 & 0 & B \\
\hline Chidorus sphaericus + Chidorus sp. & 19 & 0 & 0 & 16 & 0 & 100 & $\mathrm{~F}$ \\
\hline Eurycercus lamellatus & 0 & 0 & 19 & 62 & 56 & 166 & $\mathrm{~F}$ \\
\hline Sida crystallina & 9 & 0 & 19 & 31 & 0 & 66 & $\mathrm{~F}$ \\
\hline Simocephalus vetulus & 0 & 0 & 10 & 0 & 0 & 33 & $\mathrm{~F}$ \\
\hline Simocephalus expinosus & 19 & 0 & 38 & 47 & 0 & 166 & $\mathrm{~F}$ \\
\hline Simocephalus sp. & 0 & 0 & 0 & 0 & 0 & 0 & $\mathrm{~F}$ \\
\hline Alona quadrangularis & 9 & 0 & 0 & 0 & 0 & 33 & $\mathrm{~F}$ \\
\hline Pleuroxus sp. & 37 & 0 & 0 & 0 & 0 & 0 & $\mathrm{~F}$ \\
\hline Acroperus harpae & 0 & 0 & 0 & 0 & 0 & 0 & $\mathrm{~F}$ \\
\hline Daphnia pulex & 346 & 372 & 392 & 622 & 1324 & 763 & $\mathrm{~F}$ \\
\hline Non identified cladocera + other Daphnia & 19 & 16 & 0 & 0 & 28 & 166 & $\mathrm{~F}$ \\
\hline Pseudocandona albicans & 1 & 0 & 8 & 8 & 0 & 0 & DF \\
\hline Ilyocypris bradyi & 0 & 0 & 0 & 0 & 0 & 0 & DF \\
\hline Heterocypris salina & 0 & 0 & 0 & 0 & 0 & 0 & DF \\
\hline
\end{tabular}

\section{6}




\begin{tabular}{|c|c|c|c|c|c|c|c|}
\hline \multirow[b]{2}{*}{ Таха } & \multirow[b]{2}{*}{$\mathrm{C}$} & \multirow[b]{2}{*}{ C } & \multicolumn{2}{|c|}{ Sampled basin } & \multirow[b]{2}{*}{$\mathrm{C}$} & \multirow[b]{2}{*}{$C$} & \multirow[b]{2}{*}{ Feeding groups } \\
\hline & & & $\mathrm{C}$ & $\mathrm{C}$ & & & \\
\hline Cypridopsis vidua & 2 & 0 & 4 & 8 & 0 & 1 & DF \\
\hline Bradleystrandesia obliqua & 3 & 3 & 12 & 40 & 0 & 2 & $\mathrm{~F}$ \\
\hline Limmocythere inopinata & 0 & 0 & 0 & 0 & 0 & 0 & DF \\
\hline Gammarus sp. & 0 & 1 & 0 & 0 & 0 & 0 & Shr/P \\
\hline Cloeon sp. & 16 & 7 & 27 & 54 & 27 & 26 & $\mathrm{~B}$ \\
\hline Caenis sp. & 0 & 0 & 0 & 0 & 0 & 0 & Shr/D \\
\hline Hydroptilidae agrayla & 0 & 0 & 1 & 0 & 0 & 0 & $\mathrm{G} / \mathrm{S}$ \\
\hline Haliplidae haliplus & 0 & 0 & 0 & 0 & 0 & 0 & Shr \\
\hline Gyrinidae gyrinus + Hydrophilidae berosus + Elmidae esol & 0 & 0 & 2 & 0 & 1 & 1 & $\mathrm{P}$ \\
\hline Chironomidae Tanytarsini & 40 & 6 & 51 & 31 & 16 & 121 & F/DF \\
\hline Chironomidae Chironominae & 16 & 2 & 13 & 7 & 8 & 2 & F/DF \\
\hline Chironomidae Orthocladinae & 0 & 0 & 2 & 1 & 0 & 0 & $\mathrm{R} / \mathrm{DF}$ \\
\hline Chironomidae Tanypodinae & 5 & 1 & 3 & 2 & 0 & 1 & $\mathrm{P}$ \\
\hline Nymphs of chironomidae & 2 & 1 & 0 & 2 & 8 & 1 & $\mathrm{P} / \mathrm{F} / \mathrm{DF} / \mathrm{S}$ \\
\hline Chaoborus sp. & 0 & 0 & 2 & 1 & 0 & 1 & $\mathrm{P}$ \\
\hline Ceratopogoninae & 0 & 0 & 0 & 1 & 0 & 0 & D \\
\hline Dasyhelinae & 0 & 0 & 0 & 0 & 0 & 0 & D \\
\hline Other diptera & 0 & 0 & 2 & 2 & 0 & 1 & $\mathrm{P}$ \\
\hline Libellulidae + Sympetrinae + Plactycnemididae & 1 & 2 & 1 & 2 & 0 & 0 & $\mathrm{P}$ \\
\hline
\end{tabular}

